UNITED STATES DEPARTMENT OF THE INTERIOR GEOLOGICAL SURVEY

\title{
GENERALIZED ISOPACH MAP OF TERTIARY SEDIMENTARY ROCKS, WESTERN OREGON AND WASHINGTON AND ADJACENT CONTINENTAL MARGIN
}

\section{By}

P. D. Snavely, Jr. and H. C. Wagner

\author{
Open-File Report \\ 80-889
}

This report is preliminary and has not been edited or reviewed for conformity with Geological Survey standards or nomenclature. 


\section{GENERALIZED ISOPACH MAP OF TERTIARY SEDIMENTARY ROCKS, WESTERN OREGON AND WASHINGTON AND \\ ADJACENT CONTINENTAL MARGIN}

By

P. D. Snavely, Jr. and H. C. Wagner

The generalized isopach map of predominantly sedimentary rocks of Tertiary age in western oregon and Washington and the adjacent continental margin was constructed from stratigraphic data obtained from onshore and offshore exploration wells and measured outcrop sections, and the interpretation of gravity, magnetic, and USGS 24-channel seismic reflection data. Offshore isopachs represent minimum thicknesses due to the paucity of drill holes that penetrated the economic basement in respect to oil and gas potential.

The base of the Tertiary sequence in the Oregon and Washington coast ranges is Paleocene to middle Eocene oceanic basalts. The low-grade-metamorphosed sedimentary rocks in the core of the olympic Mountains are considered economic basement even though they are temporally equivalent to some of the isopached sedimentary rocks. Pre-Tertiary rocks underlie the Tertiary strata in the southern part of the oregon Coast Range and in the Puget soundBellingham basin area. In most places offshore, Tertiary strata overlie oceanic crust that ranges in age from early Eocene to late Miocene (Snavely and others, 1980). However, on the southern oregon shelf the nature of the basement beneath lower Eocene sandstone is not known.

New seismic reflection and refraction data are required to better estimate the total thickness of Tertiary strata in the province, particularly on the continental margin and in the Puget Sound-Willamette Valley lowlands. 
A copy of the isopach map may be examined at U.S. Geological Survey office, Room B-164, Deè Creek Facility, 345 Middlefield Road, Menlo Park, California.

\section{References}

Braislin, D. B., Hastings, D. D., and Snavely, P. D., Jr., 1971, Petroleum potential of western Oregon and Washington and adjacent continental margin: American Association of Petroleum Geologists, Memoir 15, p. 229238.

Snavely, P. D., Jr., Pearl, J. E., and Lander, D. L., 1977, Interim report on petroleum resources potential and geologic hazards in the outer continental shelf--oregon and Washington Tertiary province: U.S. Geological Survey Open-File Rept. 77-282, 64 p.

Snavely, P. D., Jr., Wagner, H. C., and Lander, D. L., 1980, Geologic cross section of the central Oregon continental margin: Geological society of American Map and Chart Series, MC-28J. 